www.nature.com/leu

\title{
ERRATUM
}

\section{P-Glycoprotein as a therapeutic target: good news}

AA Shtil

\author{
Correction to: Leukemia (2002) \\ doi:10.1038/sj.leu.2402664
}

Leukemia (2002) 16, 2347. doi:10.1038/sj.leu.2402789

In the above commentary published in the October issue of Leukemia the author refers to the paper, 'The cyclosporin
PSC 833 increases survival and delays engraftment of human multidrug resistant leukaemia cells in xenotransplanted NOD-SCID mice' by Lehne et al, as being 'in this issue'. We apologise that due to an oversight the paper by Lehne et al was not included in the October issue and will not now be published until Volume 16, Number 12, December 2002 issue. 